\title{
NRXN1 wt Allele
}

National Cancer Institute

\section{Source}

National Cancer Institute. NRXN1 wt Allele. NCI Thesaurus. Code C82880.

Human NRXN1 wild-type allele is located in the vicinity of 2p16.3 and is approximately $1112 \mathrm{~kb}$ in length. This allele, which encodes neurexin-1-alpha protein and neurexin-1beta protein, plays a role in the mediation of both cellular adhesion and signal transduction. Mutations in the gene may be associated with autism and copy number variation has been observed in patients with schizophrenia. 